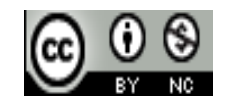

Jurnal Bimbingan Konseling Indonesia is licensed under

A Creative Commons Attribution-Non Commercial 4.0 International License.

\title{
IMPLEMENTASI LAYANAN INFORMASI TEKNIK ANALISIS TRANSAKSIONAL (AT) TERHADAP PEMANFAATAN INTERNET PESERTA DIDIK SMP NEGERI 2 METRO
}

\author{
Karwono $^{1)}$, Marliza Muchtar ${ }^{2)}$, Hadi Pranoto ${ }^{3)}$ \\ ${ }^{1)}$ Universitas Muhammadiyah Metro, Metro Lampung Indonesia \\ E-mail: karwono@yahoo.com \\ ${ }^{2)}$ Guru BK SMP Negeri 2 Metro, Metro Lampung Indonesia \\ E-mail:ieza_adli@yahoo.co.id \\ ${ }^{3)}$ Universitas Muhammadiyah Metro, Metro Lampung Indonesia \\ E-mail: hadipranoto21@gmail.com
}

\begin{abstract}
Abstrak. Tujuan penelitian ini untuk mengetahui implementasi layanan informasi teknik AT terhadap pemanfaatan internet peserta didik. Target tujuan jangka panjang setelah penelitian ini adalah membuat layanan informasi teknik AT tidak hanya terhadap pemanfaatan internet saja namun bisa perluas dengan permasalahan lain yang dapat diselesaikan dengan teknik AT dan layanan Informasi. Penelitian ini menggunakan metode penelitian Action Research atau Penelitian Tindakan yang diterapkan dalam Layanan Bimbingan dan Konseling dapat disebut PTL (Penelitian Tindakan Layanan). Subjek Penelitian kelas VIII F SMP Negeri 2 Metro. Pengumpulan data dalam penelitian ini adalah dengan cara observasi dan catatan lapangan. Teknik-teknik observasi yang digunakan dalam penelitian ini adalah observasi terus terang. Sedangkan teknik catatan lapangan untuk melihat kegiatan setiap siklusnya dan persentase kegiatan layanan klasikal berlangsung di kelas. Hasil implementasi layanan informasi teknik AT terhadap pemanfaatan internet tiap siklusnya terjadi meningkat dengan baik.
\end{abstract}

Kata Kunci: Layanan Informasi; Analisis Transaksional (AT); Pemanfaatan Internet

\section{PENDAHULUAN}

Layanan informasi merupakan layanan dalam bimbingan dan konseling yang sifatnya klasikal (layanan di kelas), memberi informasi-informasi yang sifatnya edukatif bersifat umum dan bebas dengan berbagai bidang pribadi, sosial belajar dan karier. Analisis Transaksional disini digunakan sebagai teknik dalam layanan informasi yang diharapkan dapat digunakan dalam layanan informasi karena melihat kegiatan dengan pripsip AT yaitu "im ok your ok dan im not ok, youre not ok".

Menurut Corey [1] prosedur teori analisis transaksional:

1. AT adalah suatu bentuk terapi berdasarkan kontrak. Suatu kontrak dalam AT menyiratkan bahwa sesorang akan berubah. Kontrak haruslah spesifik, ditetapkan secara jelas, dan dinyatakan secara ringkas. Kontrak menyatakan apa yang akan dilakukan oleh peserta didik, bagaimana peserta didik akan melangkah kearah tujuantujuan yang telah ditetapkan, dan kapan peserta didik mengetahui kapan kontraknya habis.

2. Penetapan ego state yang digunakan, menurut gerald corey ada tiga asusmsi yaitu ego orang tua, ego dewasa, ego anak.

3. Kontrak yang digunakan berupa pernyataan yang dibuat sendiri peserta didik. Kontrak harus spesifik dan melukiskan cara-cara yang sesungguhnya digunakan dalam terapi, baik terapi individual maupun terapi kelompok.

4. Pemahaman ego state yang dilakukan peserta didik dalam AT dapat menciptakan lingkungan yang memungkinkan peserta didik dapat membuat putusanputusan baru dalam hidupnya dan keluar dari rencana kehidupan yang menghambat perkembangannya.

Dapat dilihat bahwa dalam pelaksanaanya layanan informasi mempersiapkan peserta didik untuk bersedia dan 
siap menerima materi layanan yang diberikan oleh guru BK khususnya terkait informasi-informasi yang edukatif dan dengan adanya teknik AT (Analisis Transaksional) melihat peserta didik untuk lebih siap menerima layanan informasi yang diberikan oleh guru BK, karena dengan prinsip AT “im ok your ok" ketika guru BK siap memberikan layanan maka peserta didikpun siap, dan ketika Guru BK belum siap memberikan layanan informasi tersebut maka peserta didikpun belum siap dan belum dapat diberikan layanan informasi.

Menurut Alyusi [2] pemanfaatan internet yang baik untuk digunakan adalah Pemanfaatan internet yang baik dapat digunakan untuk email dan chatting dalam rangka berinteraksi antar satu orang dengan lainnya serta mencari berbagai informasi-informasi penting [3]. Hal ini dapat di analisis bahwa remaja dapat menggunakan aplikasi internet seperti email, chatting sebagai alat untuk menjalin hubungan online dan sebagai modal untuk pengembangan sosial mereka untuk mengekspresikan diri.

Penelitian Tindakan Layanan ini memanfaatkan layanan informasi tentang pemanfaatan internet yang nantinya akan di berikan tindakan implementasinya pada peserta didik khususnya di SMP Negeri 2 Metro pada Kelas VIII F.

\section{METODE}

\section{A. METODE PENELITIAN}

Metode penelitian ini adalah penelitian tindakan (action research), yaitu salah satu pemecahan strategi pemecahan masalah yang memanfaatkan tindakan nyata dan proses pengembangan kemampuan dalam mendeteksi dan memecahkan masalah dengan menggunakan tindakan layanan sehingga desain penelitian yang digunakan adalah Penelitian Tindakan Layanan (PTL).

Menurut Aqib [4] penelitian tindakan adalah kajian tentang situasi sosial dengan maksud untuk meningkatkan kualitas tindakan di dalamnya. Dilakukannya PTL adalah dalam rangka guru bersedia untuk mengintropeksi, bercermin, merefleksi atau mengevaluasi dirinya sendiri sehingga kemampuannya sebagai guru diharapkan cukup profesional.

Fakta yang dimaksud dari penelitian ini adalah adanya manfaat layanan informasi dalam bimbingan klasikal teknik AT dalam meningkatkan pemahaman pemanfaatan internet siswa kelas VIII.F Semester Genap SMP Negeri 2 Metro Tahun Pelajaran 2018/2019. Digunakan metode penelitian tindakan layanan, dalam prakteknya penelitian tindakan menggabungkan tindakan bermakna dengan prosedur penelitian. Ini adalah suatu upaya pemecahan masalah sekaligus mencari dukungan ilmiahnya. Pihak yang terlibat (guru, instruktur, peneliti, atau kepala sekolah) mencoba dengan sadar merumuskan suatu tindakan atau intervensi yang diperhintungkan dapat memecahkan masalah atau memperbaiki situasi dan kemudian secara cermat mengamati pelaksanaannya untuk memahami tingkat keberhasilannya. Maka dapat diharapkan data yang didapat lebih lengkap, mendalam, kredibel dan bermakna, sehingga tujuan penelitian dapat tercapai.

\section{B. SUBYEK PENELITIAN}

Subyek penelitian tindakan layanan ini adalah siswa kelas VIII F SMP Negeri 2 Metro Semester Ganjil Tahun Pelajaran 2018/2019, dari 30 siswa. Penelitian tindakan kelas ini dilakukan dengan menggunakan layanan informasi teknik AT terhadap pemanfaatan internet siswa.

\section{RANCANGAN PENELITIAN}

Langkah-langkah yang dilakukan dalam penelitian ini adalah kegiatan-kegiatan yang berbentuk siklus yang mengacu pada model yang ditemukan oleh beberapa ahli. Menurut Hidayat dan Badrujaman [5] secara garis besar terdapat empat tahap yaitu perencanaan, pelaksanaan/melakukan tindakan, pengamatan dan refleksi adalah sebagai berikut:

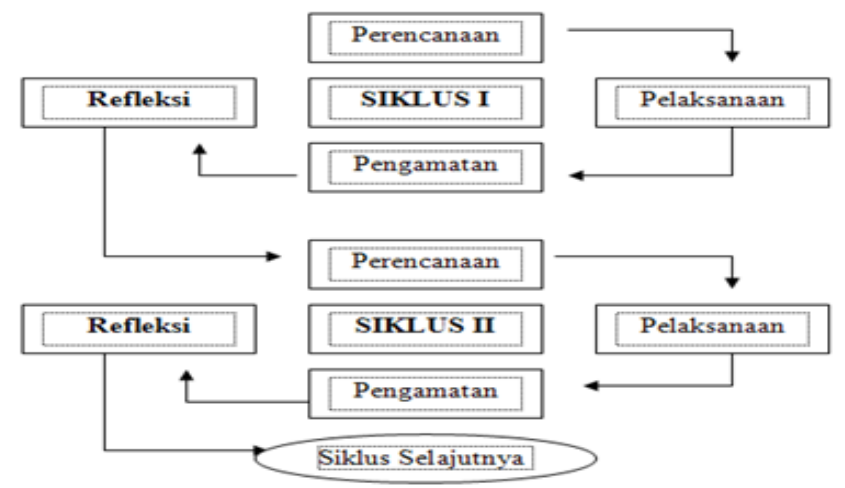

Gambar 1. Model Tahapan dalam Penelitian Tindakan Layanan (Sulipan, 2007) dalam [5]

Penjelasan gambar langkah siklus dapat dilihat di bawah ini:

1. Pra Siklus

a. Perencanaan

Tahap perencanaan ini sebagai berikut:

1) Merencanakan sekolah yang akan dilakukan pelaksanaan tindakan layanan yaitu di SMP Negeri 2 Metro.

2) Mempersiapkan bahan/pedoman wawancara yang akan ditanyakan kepada guru BK di SMP Negeri 2 Metro.

3) Menetapkan subjek penelitian berdasarkan tujuan dalam penelitian tindakan layanan.

4) Menyusun rencana tindakan layanan informasi di SMP Negeri 2 Metro.

b. Pelaksanaan

Tahap pelaksanaan tindakan layanan ini sebagai berikut:

1) Merancang kegiatan layanan informasi dalam bimbingan klasikal yang akan diberikan.

2) Merencanakan materi dalam layanan informasi dalam bimbingan klasikal.

3) Menetapakan materi layanan informasi dalam bimbingan klasikal yang akan dilaksanakan pada setiap siklus. 
4) Menyusun silabus bimbingan konseling dan RPL (Rencana Pelaksanaan Layanan) serta pada setiap siklus penelitian tindakan layanan.

c. Pengamatan

Tahap pengamatan tindakan layanan ini sebagai berikut:

a. Menyusun pedoman lembar pengamatan penelitian tindakan layanan baik proses maupun hasil.

b. Menyusun lembar pengamatan untuk siswa.

d. Refleksi

Pada tahap refleksi kegiatan layanan ini peneliti mengecek dan recek dari tahap 1 sampai tahap 3 untuk dianalisis apakah perlu dilakukan tindakan apa tidak. Kalau tidak perlu dilakukan tindakan karena mencapai kriteria yang telah penulis tetapkan yaitu sebesar $\geq 75 \%$ baik proses maupun hasil.

2. Siklus I

Layanan Pertemuan Pertama dan Kedua

a. Perencanaan

Tahap perencanaan ini adalah sebagai berikut:

1) Merancang jumlah siklus berdasarkan waktu yang tersedia.

2) Menetapkan kelas penelitian yaitu kelas VIII F SMP Negeri 2 Metro.

3) Menetapkan materi layanan, yaitu materi layanan topik bahasan tentang Pemanfaatan Internet.

4) Menyusun RPL (Rencana Pelaksanaan Layanan) bimbingan dan konseling

5) Menyiapkan lembar observasi/pengamatan.

b. Pelaksanaan

Tahap pelaksanaan tindakan layanan ini sebagai berikut:

1) Melaksanakan kegiatan layanan informasi teknik AT dalam bimbingan klasikal.

2) Melakukan absensi kepada siswa.

3) Menjelaskan maksud dan tujuan pemberian layanan informasi dalam bimbingan klasikal.

4) Menyampaikan deskripsi singkat materi layanan.

5) Memberikan kesempatan kepada siswa untuk bertanya dan berdiskusi dengan teman yang lain.

c. Pengamatan

Tahap pengamatan tindakan layanan ini sebagai berikut:

1) Peneliti mengamati apakah materi yang disampaikan dapat diterima dengan baik oleh siswa.

2) Peneliti mengamati kegiatan layanan informasi teknik AT dalam bimbingan klasikal yang diikuti oleh siswa.

3) Peneliti mengamati apakah sudah ada perubahan pada siswa setelah mengikuti layanan informasi teknik AT dalam bimbingan klasikal.

4) Kolaborator teman sejawat mengamati aktivitas peneliti dan siswa pada saat peneliti memberikan layanan.

d. Refleksi

Pada tahap ini dilakukan analisis data yang telah ada dipergunakan untuk melakukan evaluasi terhadap proses dan hasil yang ingin dicapai. Refleksi dimaksudkan sebagai upaya untuk mengkaji apa yang telah terjadi atau belum terjadi, apa yang dihasilkan, kenapa hal itu terjadi, dan apa yang perlu dilakukan selanjutnya. Hasil refleksi digunakan untuk menetapkan langkah selanjutnya dalam upaya untuk menghasilkan perbaikan pada siklus II.

3. Siklus II

a. Layanan Pertemuan Pertama

1) Perencanaan

Tahap perencanaan pada siklus II ini adalah sebagai berikut:

a) Penyusunan RPL (Rencana Pelaksanaan Layanan) Layanan Informasi dengan topik Pemanfaatan Internet.

b) Penyusunan lembar kerja siswa sesuai dengan indikator yang ingin dicapai.

c) Membuat soal lembar pengamatan aktivitas pemanfaatan internet siswa untuk mengetahui hasil layanan penguasaan informasi.

d) Menanyakan/memeriksa kesiapan siswa mengikuti kegiatan layanan informasi dalam bimbingan klasikal teknik AT

e) Memberikan penjelasan pada siswa tentang layanan kegiatan layanan informasi dalam bimbingan klasikal teknik AT.

2) Pelaksanaan

Tahap pelaksanaan tindakan layanan pada siklus II ini sebagai berikut:

a) Melakukan pretes untuk mengukur konsepsi awal siswa tentang pemahaman informasi yang diperoleh melalui kegiatan layanan informasi dalam bimbingan klasikal teknik AT

b) Menyampaikan tujuan dan indikator yang ingin dicapai serta memotivasi siswa.

c) Melakukan games "Senam Tangan Ok" supaya siswa lebih bersemangat dan interaktif dalam kegitan layanan.

d) Membentuk kelompok diskusi dan melakukan evaluasi untuk mengetahui hasil layanan yang dilakukan oleh guru pembimbing.

e) Melakukan perbandingan perubahan yang diperoleh siswa pada setiap siklus tindakan.

3) Pengamatan

Tahap pengamatan tindakan layanan pada siklus II ini peneliti melakukan pengamatan terhadap aktivitas siswa dalam mengikuti kegiatan kegiatan layanan informasi dalam bimbingan klasikal teknik AT. Penulis sebagai peneliti mengamati pelaksanaan diskusi untuk mengetahui pemanfaatan internet siswa dalam pelaksanaan bimbingan dan konseling setelah diberikan kegiatan layanan informasi dalam bimbingan klasikal teknik AT.

4) Refleksi

Refleksi pada siklus II ini untuk mengetahui hasil atau dampak dari kegiatan layanan informasi dalam bimbingan klasikal teknik AT yang dilakukan oleh guru pembimbing dengan berdasarkan indikator keberhasilan. Refleksi pada siklus II ini dengan melakukan evaluasi dan analisis terhadap proses dan hasil yang dicapai dalam pemberian layanan. Apabila dalam siklus II pertemuan pertama belum berhasil, maka dilanjutkan ke 
siklus II pertemuan kedua berikutnya sampai masalah yang diteliti menunjukan hasil-hasil seperti yang diharapkan.

b. Layanan Pertemuan ke-dua Siklus II

1) Perencanaan

Tahap perencanaan pada siklus II pertemuan kedua ini adalah sebagai berikut:

a) Penyusunan layanan informasi dalam bimbingan klasikal teknik AT dengan topik Pemanfaatan Internet.

b) Menanyakan/memeriksa kesiapan siswa mengikuti kegiatan layanan informasi dalam bimbingan klasikal teknik AT.

c) Menyusun silabus bimbingan dan konseling dan laporan pelaksanaan hasil tindakan layanan informasi dalam bimbingan klasikal teknik AT pada siklus-siklus yang telah dilaksanakan sesuai pelaksanaan tindakan layanan bimbingan konseling.

2) Pelaksanaan

Tahap pelaksanaan tindakan layanan pada siklus II ini sebagai berikut:

a) Melakukan pretes untuk mengukur konsepsi awal siswa tentang pemahaman informasi yang diperoleh melalui layanan informasi dalam bimbingan klasikal teknik AT.

b) Melakukan apersepsi dari kegiatan layanan informasi dalam bimbingan klasikal teknik AT yang telah dilakukan pada siklus sebelumnya.

c) Melakukan senam "Senam Otak" supaya siswa lebih bersemangat dan interaktif dalam kegitan layanan dan tidak merasa bosan.

d) Melakukan perbandingan perubahan yang diperoleh siswa pada setiap siklus tindakan.

3) Pengamatan

Tahap pengamatan tindakan layanan pada siklus II pertemuan kedua dalam penelitian ini melakukan pengamatan terhadap jalannya kegiatan layanan informasi dalam bimbingan klasikal teknik AT dalam pemanfaatan internet siswa kelas VIII F SMP Negeri 2 Metro.

4) Refleksi

Refleksi pada siklus II pertemuan kedua ini untuk mengetahui hasil atau dampak dari layanan informasi dalam bimbingan klasikal teknik AT yang dilakukan oleh guru pembimbing dengan berdasarkan indikator keberhasilan. Refleksi pada siklus II ini dengan melakukan evaluasi dan analisis terhadap proses dan hasil yang dicapai dalam pemberian layanan. Apabila dalam siklus II pertemuan pertama belum berhasil, maka dilanjutkan kesiklus berikutnya sampai masalah yang diteliti menunjukan hasil hasil seperti yang diharapkan. Jika dalam siklus II pertemuan pertama belum tercapai minimal $\geq 75 \%$ baik proses maupun hasil, maka siklus masih dilanjutkan kesiklus berikutnya sampai masalah yang diteliti menunjukan hasil hasil seperti yang diharapkan. Apabila dalam siklus II pertemuan kedua telah tercapai $\geq 75 \%$, siklus dihentikan.

\section{INSTRUMEN PENELITIAN}

Instrumen penelitian adalah alat atau fasilitas yang digunakan peneliti dalam mengumpulkan data agar pekerjannya lebih mudah dan hasilnya lebih baik, dalam arti lebih cermat, lengkap dan sistematis sehingga lebih mudah diolah.

\section{E. UJI VALIDITAS}

Validitas adalah suatu ukuran yang menunjukan tingkat-tingkat kevalidtan atau kesahihan suatu instrumen. Suatu instrumen yang valid atau sahih mempunyai validitas tinggi. Sebaliknya, instrumen yang kurang valid berarti memiliki validitas rendah [6].

Instrumen motivasi belajar yang telah disusun selanjutnya diperlukan uji validitas isi yaitu keterkaitan erat antara kecocokan butir-butir tes dengan tujuan yang diukur. Prosedur untuk menilai validitas isi mencakup yaitu menjelaskan komponen pemanfaatan internet, menetapkan indikator yang diukur dari masing-masing komponen, mengembangkan deskripsi untuk masing-masing indikator yang diukur lihat pada tabel I.

TABEL I

HASIL UJI VALIDITAS LEMBAR OBSERVASI

\begin{tabular}{|c|c|c|}
\hline $\begin{array}{c}\text { Definisi } \\
\text { oprasional }\end{array}$ & Indikator & $\begin{array}{c}\text { Rancangan lembar } \\
\text { observasi }\end{array}$ \\
\hline \multirow[t]{3}{*}{$\begin{array}{l}\text { Pemanfaatan } \\
\text { Internet }\end{array}$} & $\begin{array}{l}\text { Paham dalam } \\
\text { penggunaan internet }\end{array}$ & $\begin{array}{l}\text { Peserta didik menjadi } \\
\text { lebih paham dalam } \\
\text { penggunaan internet }\end{array}$ \\
\hline & $\begin{array}{l}\text { Menjadikan internet } \\
\text { sebagai sumber } \\
\text { informasi yang } \\
\text { bebas }\end{array}$ & $\begin{array}{l}\text { Peserta didik tidak } \\
\text { menjadikan internet } \\
\text { sebagai sumber } \\
\text { informasi yang bebas }\end{array}$ \\
\hline & $\begin{array}{l}\text { Memanfaatkan } \\
\text { fasilitas internet } \\
\text { dengan baik. }\end{array}$ & $\begin{array}{l}\text { Peserta didik } \\
\text { memanfaatkan } \\
\text { fasilitas internet } \\
\text { dengan baik }\end{array}$ \\
\hline
\end{tabular}

\section{F. TEKNIK PENGUMPULAN DATA}

Teknik pengumpulan data yang digunakan antara lain:

\section{Observasi}

Jenis observasi yang digunakan adalah observasi partisipasi yaitu kondisi dimana peneliti benar-benar ikut serta (terlibat) dalam aktivitas pembelajaran yang dibuat dan bertujuan utama untuk mengobservasi aktivitas, orangorang, dan aspek fisik dalam suatu kondisi tertentu. Dengan demikian pengamat melakukan dua peranan sekaligus, yaitu peneliti menggunakan dua orang observer untuk mengamati peneliti pada saat memberikan layanan baik proses maupun setelah mengikuti layanan sebagai anggota resmi dari kelas yang diamatinya.

Observasi adalah suatu cara mengumpulkan data atau keterangan dengan mengadakan pengamatan secara langsung suatu objek (kegiatan-kegiatan yang sedang berlangsung) dalam periode tertentu [7].

Observasi cara yang paling efektif adalah melengkapi format atau blangko pengamatan sebagai instrumen, format 
yang disusun berisi item-item tentang kejadian atau tingkah laku [8].

Dengan demikian observasi merupakan salah satu metode pengumpulan data yang pada hakekatnya mengamati gejala fisik dan sosial yang nampak sesuai dengan keadaan sebenarnya.

\section{Catatan Lapangan}

Dalam penelitian ini menggunakan catatan lapangan deskriptif. Catatan lapangan deskriptif adalah catatan yang digunakan oleh peneliti yang mendeskripsikan hasil rekaman peristiwa yang terjadi di lapangan yaitu pada saat peneliti melakukan kegiatan layanan Informasi Teknik AT peneliti mengamati proses kegiatan dalam pelaksanaan layanan Informasi Teknik AT dalam layanan bimbingan klasikal pada setiap pertemuan.

\section{G. KRITERIA KEBERHASILAN}

Persentasi ketercapaian indikator pemanfaatan internet peserta didik selama mengikuti kegiatan layanan Informasi Teknik AT dalam layanan bimbingan klasikal dapat dijelaskan bahwa presentasi ketercapaian indikator pemanfaatan internet peserta didik meningkat dari setiap siklusnya. Adapun indikatornya dapat dilihat pada tabel II berikut:

TABEL II .

INDIKATOR PEMANFAATAN INTERNET

\begin{tabular}{llc}
\hline No & \multicolumn{1}{c}{ Indikator yang diamati } & Target \\
& & $\%$ \\
\hline $1 . \quad$ & $\begin{array}{l}\text { Peserta didik menjadi lebih paham dalam } \\
\text { penggunaan internet }\end{array}$ & $\geq 75$ \\
2. & $\begin{array}{l}\text { Peserta didik tidak menjadikan internet } \\
\text { sebagai sumber informasi yang bebas } \\
\text { Peserta didik memanfaatkan fasilitas } \\
\text { internet dengan baik. }\end{array}$ & $\geq 75$ \\
\hline
\end{tabular}

Berdasarkan tabel II di atas maka, dapat dijelaskan bahwa untuk mengetahui hasil pemanfaatan internet peserta didik setelah dilakukan layanan Informasi Teknik AT yaitu hasil pemanfaatan internet peserta didik meningkat dari setiap siklusnya dan peningkatan hasil pemanfaatan internet dikatakan berhasil jika pada akhir siklusnya telah memperoleh nilai ketuntasan dan tindakan layanan atau siklus dihentikan jika peserta didik mencapai $75 \%$ dari jumlah peserta didik yaitu 75/(100 ) x $30=22.5$ atau 23 peserta didik, yang sudah ditetapkan pemerintah dalam Peraturan Pemerintah No.19 Tahun 2005 tentang Standar Nasional Pendidikan yaitu sebesar $75 \%$.

\section{H. TEKNIK ANALISIS DATA}

1. Analisis Data Kuantitatif

Dalam penelitian ini menggunakan analisis data kuantitatif deskriptif. Dalam hal ini peneliti menggunakan analisis statistik secara deskriptif. Selama kegiatan layanan Informasi Teknik AT dalam layanan bimbingan klasikal berlangsung, aktivitas peserta didik dan kinerja guru yang sesuai dengan indikator dicatat dilembar observasi. Setelah dilakukan pengobservasian, jumlah aktivitas yang dilakukan peserta didik dan guru pembimbing/peneliti dihitung, kemudian data yang diperoleh diprosentasikan dengan menggunakan rumus [9]:

$$
P=f /(N) \times 100 \%
$$

Keterangan :

$\mathrm{P}$ : Presentase

f : Frekuensi siswa dalam suatu kategori

$\mathrm{N}$ : Jumlah siswa keseluruhan

\section{Analisis Data Kualitatif}

Pada penelitian ini menggunakan analisis deskriptif kualitatif, yaitu data yang berupa informasi berbentuk kalimat yang memberi gambaran ataupun peristiwa yang terjadi selama pelaksanaan penelitian tindakan layanan (PTL) yang diperoleh dari lembar pengamatan dan catatan lapangan pada setiap pertemuan dimasing-masing siklus.

\section{HASIL DAN PEMBAHASAN}

A. HASIL

\section{SIKLUS I}

Pemanfaatan internet pada pelaksanaan tindakan siklus I nampak terjadi peningkatan baik pada setiap pertemuan I dan II penjelasan secara singkat dapat diikuti sebagai berikut:

1. Peserta didik menjadi lebih Paham dalam penggunaan internet

Berdasarkan hasil analisis dapat dilihat bahwa pada siklus I pertemuan pertama dari 30 peserta didik didapati 6 atau $20 \%$ yang mengalami peningkatan pemanfaatan penggunaan internet, begitu juga pada pertemuan ke II meningkat sebesar $40 \%$ dari $20 \%$ hasil pertemuan pertama berkaitan dengan aspek no 1. Hal ini dikarenakan peserta didik bersungguh-sungguh dalam mengikuti kegiatan layanan informasi dengan teknik AT.

2. Peserta didik tidak menjadikan internet sebagai sumber informasi yang bebas

Dapat memahami tidak menjadikan internet sebagai sumber informasi yang bebas, siklus I pertemuan pertama sebesar $20 \%$ dan pada pertemuan ke II mengalami peningkatan yaitu menjadi 30\%. Dapat dilihat bahwasannya peserta didik mulai dapat memahami internet sebagai sumber informasi dengan baik pada peserta didik, namun demikian belum keseluruhan hanya beberapa peserta didik saja.

3. Peserta didik memanfaatkan fasilitas internet dengan baik.

Pada aspek ini pada siklus I pertemuan pertama dari 30 peserta didik hanya didapati 3 atau $10 \%$ yang mengalami peningkatan, dan pada pertemuan ke II meningkat menjadi $30 \%$. Hal ini dikarenakan beberapa peserta didik sudah berani mengungkapkan pendapatnya pada kegiatan layanan bimbingan klasikal layanan informasi dengan teknik AT yang berlangsung.

Refleksi

Berdasarkan data dari hasil pelaksanaan siklus I pelaksanaan layanan informasi dengan teknik AT dalam 
bimbingan klasikal belum sesuai dengan harapan, meskipun pelaksanaan layanan informasi dengan teknik AT dalam bimbingan klasikal telah dilakukan secara maksimal sesuai dengan perencanaan yang sudah direncanakan. Oleh karena itu perlu diadakannya perbaikan pada siklus selanjutnya. Menurut informasi pengamat terdapat beberapa kekurangan pada siklus I dalam pelaksanaan tindakan layanan sehingga hasil yang diinginkan belum mencapai target yang diharapkan sebagaimana penjelasan berikut:

a. Dalam menyampaikan materi, peneliti masih kurang jelas dalam memberikan informasi, sehingga peserta didik masih merasa kesulitan untuk menerima atau memahami materi yang disampaikan karena masih ada yang berbicara sendiri dengan temannya.

b. Penggunaan waktu yang sudah siang yaitu di jam terakhir dan peserta didik banyak yang ngantuk, hal ini membuat banyak peserta didik merasa capek, lemas dan lain sebagainya sehingga kurang efektif.

Berdasarkan hasil refleksi, maka untuk itu diperlukan pelaksanaan tindakan layanan melalui siklus selanjutnya.

Sebelum Dilaksanakan Siklus II Perlu Dilaksanakan Rencana Perbaikan Tindakan Layanan

Berdasarkan hasil refleksi siklus I direkomendasikan tindakan layanan perbaikan untuk siklus II sebagai berikut :

a. Materi layanan yang akan diberikan kepada peserta didik diberitahukan terlebih dahulu sebelumnya, dengan tujuan agar peserta didik lebih siap dalam mengikuti kegiatan layanan informasi dengan teknik AT dalam bimbingan klasikal selanjutnya.

b. Menggunakan waktu yang masih pagi atau jam pertama, dengan tujuan peserta didik masih dalam keadaan fresh atau lebih semangat, menggunakan bahasa untuk usia siswa SMP.

c. Dalam menyampaikan materi dengan bahasan yang ringkas dan jelas serta menggunakan metode yang unik yaitu dengan mengisi permainan dalam BK.

\section{SIKLUS II}

Pemanfaatan internet peserta didik pada pelaksanaan tindakan layanan siklus II terjadi peningkatan pada pertemuan I dan II penjelasan secara singkat dapat dilihat penjelasannya berikut :

1. Peserta didik menjadi lebih Paham dalam penggunaan internet

Pada aspek ini peserta didik dari siklus I dan Siklus II adanya peningkatan. Pada siklus I pada aspek ini yaitu lebih tidak egois atau dapat menerima dan menghargai pendapat orang lain dengan rata-rata $30 \%$. Pada siklus II rata-rata pada aspek ini yaitu paham dalam penggunaan internet meningkat dengan rata-rata $75 \%$. Peningkatan ini disebabkan karena peserta didik lebih fokus mengikuti layanan informasi Teknik AT dalam bimbingan klasikal dan materi yang disajikan lebih mudah dimengerti oleh peserta didik sehingga peserta didik tertarik untuk memperhatikan materi layanan yang disajikan.

Pada aspek ini peserta didik pada siklus II mengalami peningkatan dibandingkan siklus I yaitu sebesar $30 \%$ menjadi $75 \%$, peningkatan tersebut sebesar $45 \%$. Karena pada aspek ini pada siklus II besar target yang ditentukan yaitu $75 \%$ maka pada aspek ini yaitu paham dalam penggunaan internet telah memenuhi target.

2. Peserta didik tidak menjadikan internet sebagai sumber informasi yang bebas

Pada aspek ini yaitu internet sebagai sumber informasi yang bebas dalam kegiatan kelompok dari siklus I dan siklus II terus mengalami peningkatan. Pada siklus I ratarata $30 \%$ pada siklus II rata-rata $75 \%$. Pada pertemuan I sebesar $70 \%$ dan pada pertemuan ke II menjadi sebesar $80 \%$. Penelitian yang dilakukan oleh peneliti menunjukkan bahwa dengan layanan informasi teknik AT maka peserta didik dapat menjadikan internet sebagai sumber informasi yang bebas dengan baik.

Pada siklus II terus mengalami peningkatan dibandingkan siklus I yaitu $30 \%$ menjadi $75 \%$, peningkatan tersebut sebesar $45 \%$. Karena pada aspek ini yaitu dapat menjadikan internet sebagai sumber informasi yang bebas dalam kegiatan kelompok pada siklus II telah memenuhi target yang ditentukan yaitu $75 \%$ maka sudah memenuhi target.

3. Peserta didik memanfaatkan fasilitas internet dengan baik.

Pada aspek ini yaitu memanfaatkan fasilitas internet dengan baik pada siklus I rata-rata sebesar 20\%, sedangkan pada siklus II rata-rata sebesar $75 \%$. Pada pertemuan I sebesar $60 \%$ dan pada pertemuan II sebesar $90 \%$. Peningkatan ini menunjukkan bahwa peserta didik dapat memanfaatkan fasilitas internet dengan baik.

Pada aspek ini yaitu memanfaatkan fasilitas internet dengan baik mengalami peningkatan dari siklus I ke siklus II yaitu $20 \%$ menjadi $75 \%$ peningkatan tersebut sebesar $55 \%$. Karena rata-rata pada aspek ini pada siklus II telah memenuhi target yang ditentukan yaitu $75 \%$ maka sudah memenuhi target.

\section{Refleksi}

Berdasarkan data dari hasil pelaksanaan siklus II pemanfaatan internet peserta didik meningkat, hasil sudah sesuai dengan harapan yang diinginkan karena layanan informasi dengan Teknik AT dalam bimbingan klasikal telah dilakukan dengan maksimal. Pada waktu ketika peneliti memberikan materi layananan semua peserta didik memperhatikan dan mendengarkan serta lebih aktif dari yang sebelumnya. Peserta didik sudah menunjukkan atau sudah memiliki pemahaman internet yang lebih baik dari sebelum mengikuti layanan informasi teknik AT dalam bimbingan klasikal. 


\section{B. PEMBAHASAN}

1. Pemanfaatan Internet

TABEL III.

RATA-RATA PEMANFAATAN INTERNET PESERTA DIDIK PADA KEGIATAN SIKLUS I DAN SIKLUS II

\begin{tabular}{|c|c|c|c|c|c|c|c|c|}
\hline \multirow[b]{2}{*}{ No } & \multirow{2}{*}{$\begin{array}{l}\text { Aktivita } \\
\text { s Yang } \\
\text { Diamati }\end{array}$} & \multirow[b]{2}{*}{$\begin{array}{c}\text { Targ } \\
\text { et }\end{array}$} & \multicolumn{2}{|c|}{ Siklus I } & \multirow[b]{2}{*}{$\begin{array}{l}\text { Rata } \\
\text {-rata }\end{array}$} & \multicolumn{2}{|c|}{ Siklus II } & \multirow[b]{2}{*}{$\begin{array}{c}\text { Rata- } \\
\text { rata }\end{array}$} \\
\hline & & & I & II & & I & II & \\
\hline 1. & $\begin{array}{l}\text { Paham } \\
\text { dalam } \\
\text { penggun } \\
\text { aan } \\
\text { internet }\end{array}$ & $75 \%$ & $20 \%$ & $40 \%$ & $30 \%$ & $70 \%$ & $80 \%$ & $75 \%$ \\
\hline 2. & $\begin{array}{l}\text { Tidak } \\
\text { menjadi } \\
\text { kan } \\
\text { internet } \\
\text { sebagai } \\
\text { sumber } \\
\text { informas } \\
\text { i yang } \\
\text { bebas }\end{array}$ & $75 \%$ & $20 \%$ & $40 \%$ & $30 \%$ & $60 \%$ & $80 \%$ & $75 \%$ \\
\hline 3. & $\begin{array}{l}\text { Memanf } \\
\text { aatkan } \\
\text { fasilitas } \\
\text { internet } \\
\text { dengan } \\
\text { baik. }\end{array}$ & $75 \%$ & $10 \%$ & $30 \%$ & $20 \%$ & $60 \%$ & $90 \%$ & $75 \%$ \\
\hline
\end{tabular}

Jumlah

$80 \%$

$225 \%$

Rata-rata

26,7

$75 \%$

Sumber : Dari Hasil Pengamatan Siklus I Sampai Siklus II

Berdasarkan tabel III di atas, dapat dilihat bahwa pemahaman internet peserta didik setiap pertemuan mengalami peningkatan. Hal ini dapat dilihat pada tabel dari siklus I sampai siklus II terjadi peningkatan pada setiap aspek.

a. Paham dalam penggunaan internet

Pada aspek ini yaitu paham dalam penggunaan internet siklus I sampai siklus II mengalami peningkatan. Pada siklus II rata-rata berkaitan dengan aspek ini meningkat dengan rata-rata $75 \%$. Pada pertemuan I sebesar $70 \%$ dan pada pertemuan ke II menjadi sebesar $80 \%$. Peningkatan ini disebabkan peserta didik lebih memperhatikan dan serius dalam mengikuti layanan informasi teknik AT, sehingga peserta didik dapat lebih baik dalam menerima materi layanan yang disajikan atau berikan oleh peneliti itu sendiri. Setelah mengikuti beberapa pertemuan peserta didik menjadi lebih memahami bagaimana untuk paham dalam penggunaan internet.

Peneliti menunjukkan bahwa layanan Informasi dengan Teknik AT dalam bimbingan klasikal dari sikus I sampai siklus ke II pada aspek ini peningkatan dari $30 \%$ menjadi $75 \%$, peningkatan tersebut sebesar $45 \%$. Karena rata-rata pada aspek ini pada siklus II telah memenuhi kriteria keberhasilan yaitu $75 \%$ maka aspek ini telah memenuhi target. b. Tidak menjadikan internet sebagai sumber informasi yang bebas

Pada aspek ini yaitu tidak menjadikan internet sebagai sumber informasi yang bebas terus mengalami peningkatan dari siklus I sampai pada siklus II. Pada siklus I yaitu 30\% pada siklus II pada aspek ini rata-rata meningkat dengan rata-rata sebesar $75 \%$. Pada pertemuan I sebesar $60 \%$ dan pada pertemuan ke II sebesar $80 \%$. Penelitian yang dilakukan peneliti menunjukkan bahwa dengan layanan informasi dengan teknik AT dalam bimbingan klasikal pada aspek ini mengalami peningkatan dari $30 \%$ menjadi $75 \%$, peningkatan tersebut sebesar $45 \%$. Karena rata-rata pada aspek ini pada siklus II memenuhi kriteria yang ditentukan yaitu $75 \%$ maka telah memenuhi target.

c. Memanfaatkan fasilitas internet dengan baik.

Dengan usaha yang dilakukan terlihat pada aspek ini yaitu memanfaatkan fasilitas internet dengan baik terus mengalami peningkatan dari siklus I sampai pada siklus II. Pada siklus I yaitu 20\% pada siklus II meningkat dengan rata-rata sebesar $75 \%$. Pada pertemuan I sebesar $60 \%$ dan pada pertemuan ke II sebesar 90\%. Penelitian yang dilakukan peneliti menunjukkan bahwa dengan layanan informasi teknik AT dalam bimbingan klasikal pada aspek ini mengalami peningkatan dari $20 \%$ menjadi $75 \%$, peningkatan tersebut sebesar $55 \%$. Karena rata-rata pada aspek ini pada siklus II memenuhi kriteria yang ditentukan yaitu $75 \%$ maka telah memenuhi target.

2. Implementasi Layanan Informasi dengan Teknik

Analisisi Transaksional (AT)

Dalam pengentasan masalah pemanfaatan internet melalui layanan informasi teknik AT dapat berhasil secara efektif, hal ini terlihat dari peningkatan dalam setiap aspeknya berikut ini adalah data efektifitas pelakasaan layanan informasi teknik AT dalam bimbingan klasikal untuk pengentasan masalah pemanfaatan internet pada pelaksanaan siklus I dilihat dari rata-rata presentase yaitu sebesar $26,7 \%$ dan pada siklus II sebesar $75 \%$, sehingga terjadi peningkata sebesar 48,3\% dan maka telah memenuhi target. Presentase yaitu $75 \%$ adalah kriteria yang digunakan oleh peneliti, senada dengan apa yang sudah ditetapkan oleh pemerintah No.19 Tahun 2005 tentang Standar Nasional Pendidikan yaitu sebesar 75\% [9]. Hasil penelitian ini yaitu dalam pengentasan masalah pemanfaatan internet melalui layanan informasi dengan teknik AT dalam bimbingan klasikal dapat berhasil secara efektif karena senada dengan tujuan layanan informasi yaitu menurut Tohirin [10] menjelaskan tujuan layanan informasi adalah:

1. Tujuan umum yaitu layanan informasi bertujuan untuk mengembangkan kemampuan bersosialisasi, khususnya kemampuan berkomunikasi peserta layanan (peserta didik).

2. Tujuan khusus yaitu layanan informasi bertujuan untuk mendorong pengembangan perasaan, pikiran, persepsi, wawasan dan sikap yang menunjang perwujudan tingkah laku yang efektif, yakni peningkatan kemampuan berkomunikasi baik verbal maupun non verbal.

Dengan layanan informasi dengan teknik AT dapat memberikan peserta didik untuk lebih mudah berinteraksi 
karena menggunakan teknik AT antara lain Im Ok Ure Oke. Itu adalah kesepakatan dalam kegiatan layanan informasi teknik AT (Analisis Transaksional).

\section{KESIMPULAN}

Setelah melakukan semua tahapan penelitian dari pengumpulan data, analisis, pemaparan data sampai pembahasan terhadap semua temuan penelitian maka dapat disimpulkan: Melalui layanan informasi dengan Teknik AT (Analisis Transaksional) dalam bimbingan klasikal yang diberikan oleh guru BK dapat meningkatkan pemanfaatan internet peserta didik kelas VIII F SMP Negeri 2 Metro Semester Ganjil Tahun Pelajaran 2018/2019. Terdapat peningkatan Hasil Implementasi Pemanfaatan Internet peserta didik pada siklus I dilihat dari rata-rata presentase yaitu sebesar $26,7 \%$ dan pada siklus II sebesar $75 \%$, sehingga terjadi peningkatan sebesar $48,3 \%$.

\section{DAFTAR PUSTAKA}

[1] Corey, M. S., Corey, G., \& Corey, C. (2013). Groups: Process and practice. Cengage Learning.

[2] Alyusi, S. D. (2016). Media Sosial. Jakarta: Prenada Media Group.

[3] Kadir, A. (2003). Pengenalan Teknologi Informasi. Jakarta: ANDI.

[4] Aqib, Z. (2006). Penelitian Tindakan Kelas untuk Guru. Bandung: Yrama Widya.

[5] Hidayat, D. R., \& Badrujaman, A. (2012). Penelitian Tindakan dalam Bimbingan dan Konseling. Jakarta: Indeks.

[6] Arikunto, S. (2010). Prosedur Penelitian Suatu Pendekatan Praktik. Jakarta : Rineka Cipta.

[7] Pranoto, H. (2016). Upaya Meningkatkan Percaya Diri Siswa Melalui Layanan Bimbingan Kelompok Di Sma Negeri 1 Sungkai Utara Lampung Utara. Jurnal Lentera Pendidikan Pusat Penelitian LPPM UM Metro, 1(1), 100-111.

[8] Arikunto, S. (2011). Penilaian dan Penelitian Bidang Bimbingan dan Konseling. Yogyakarta : Aditya Media.

[9] Pranoto, H. (2013). Efforts to Improve Learning Motivation of Student with Content Mastery in SMP Negeri 1 Metro. GUIDENA Jurnal Ilmu Pendidikan, Psikologi, Bimbingan dan Konseling, 3(1), 31-41.

[10] Tohirin. (2009). Bimbingan dan Konseling di Sekolah dan Madrasah (Bebasis Intergrasi). Jakarta: Raja Grafindo Persada. 